\title{
STUDI KOMPARASI JUMLAH ANGKA KUMAN UDARA RUANG PERAWATAN KELAS 3 DI IRNA I RSUD PROF. DR. MARGONO SOEKARJO PURWOKERTO TAHUN 2015
}

\author{
Prili Yoshintan'), Agus Subagiyo' ${ }^{2)}$ \\ Jurusan Kesehatan Lingkungan, Politeknik Kesehatan Kemenkes Semarang, \\ Jl. Raya Baturaden KM 12 Purwokerto, Indonesia
}

\begin{abstract}
Abstrak
RSUD Prof. Dr. Margono Soekarjo Purwokerto merupakan salah satu Rumah Sakit tipe B pendidikan. Ruang perawatan di RSUD Prof. Dr. Margono Soekarjo Purwokerto terdiri dari ruang rawat inap (IRNA) dan ruang rawat jalan (IRJA).Instalasi Ruang Rawat Inap (IRNA) dibagi menjadi 2 bagian, yaitu IRNA I dan IRNA II. Tujuan penelitian ini adalah untuk mengetahui apakah ada perbedaan angka kuman udara yang ada di 7 ruang perawatan kelas III di IRNA I RSUD Prof. Dr. Margono Soekarjo.Jenis penelitian ini adalah penelitian observasional analitik dengan pendekatan cross sectional. Analisis data menggunakan One Sample Test nilai signifikan 0,058 > $\alpha$ berarti Ho di tolak. Berdasarkan hasil pemeriksaan, rata-rata angka kuman udara dari 7 ruangan yang diperiksa adalah31714.2857CFU/m ${ }^{3}$,melebihi standar KEPMENKES RI No. 1204/MENKES/SK/X/2004 tentang Persyaratan Kesehatan Lingkungan Rumah Sakit (200-500 CFU/ ${ }^{3}$ ). Rata-rata suhu adalah $29,28{ }^{\circ}$ C, rata-rata kelembaban adalah 64\%,rata-rata pencahayaan adalah 201,42 Lux, rata-rata luas lubang ventilasi adalah 2,86 \%, rata-rata kepadatan hunian adalah 6,08 $\mathrm{m}^{2}$ /orang.Peneliti menyimpulkan ruang perawatan kelas III di IRNA I belum sepenuhnya memenuhi syarat dilihat dari kualitas fisik lingkungan.Peneliti menyarankan, sebaiknya diadakan jadwal pelaksanaan desinfeksi udara di ruangan secara rutin dengan di dukung pengaturan ruangan untuk pasien baru.
\end{abstract}

Kata kunci : Rumah sakit, angka kuman udara, kesehatan lingkungan

\begin{abstract}
Hospital Prof. Dr. Margono Soekarjo Purwokerto Hospital is one type B education. Treatment rooms in hospitals Prof. Dr. Margono Soekarjo Purwokerto consisting of inpatient room (IRNA) and outpatient space (Irja). Installation Space Inpatient (IRNA) is divided into two parts, the IRNA IRNA I and II. The purpose of this study was to determine whether there are differences in the air germ numbers in the 7 treatment rooms third class in the first IRNA RSUD Prof. Dr. Margono Soekarjo. This type of research is analytic observational study with cross sectional approach. Analysis of data using One Sample Test significant value 0.058> a means Ho is rejected. Based on the results of the examination, the average number of bacteria 7 indoor air from being examined is 31714.2857 CFU / m3, exceeding the standard KEPMENKES No. 1204 / Menkes / SK / X / 2004 on Environmental Health Requirements Hospital (200-500 CFU / $\left.\mathrm{m}^{3}\right)$. The average temperature was $29.28^{\circ} \mathrm{C}$, the average humidity is $64 \%$, the average exposure was 201.42 Lux, average area of the ventilation holes is $2.86 \%$, the average population density is $6.08 \mathrm{~m}^{2}$ /people. Researchers concluded the third class in the treatment room IRNA I have not fully qualified views of the physical quality of the environment. Researchers suggest, should be held timetable for implementation in the room air disinfection routine with the support arrangement room for new patients.
\end{abstract}

Key word $\quad$ : Hospital, air germ numbers, environmental health

\section{PENDAHULUAN}

Menurut Hendrik L. Blum Derajat Kesehatan Masyarakat dipengaruhi oleh empat faktor yaitu : faktor lingkungan, perilaku manusia, pelayanan kesehatan dan keturunan. Lingkungan mempunyai pengaruh yang paling besar terhadap kesehatan masyarakat.Faktor lingkungan meliputi lingkungan fisik, lingkungan biologi, dan lingkungan kultural.Jhon Gordon menggambarkan adanya interaksi antara 3 faktor yaitu faktor lingkungan (environtment), pejamu (host), dan penyebab penyakit (agent).Timbulnya suatu penyakit adalah bila terjadi ketidakseimbangan antara ketiga faktor tersebut, misalnya penyakit yang terjadi akibat dari faktor lingkungan yang memburuk.

Salah satu sarana kesehatan yang memberikan pelayanan kesehatan untuk mempercepat peningkatan derajat kesehatan adalah rumah sakit.Menurut 
Undang-Undang Republik Indonesia nomor 44 Tahun 2009, rumah sakit adalah institusi pelayanan kesehatan yang menyelenggarakan pelayanan kesehatan perorangan secara paripurna yang menyediakan pelayanan rawat inap, rawat jalan, dan gawat darurat.Rumah sakit sebagai institusi pelayanan kesehatan dimana di dalamnya terdapat bangunan, peralatan, manusia (petgas, pasien, dan pengunjung) dan kegiatan pelayanan kesehatan.

Rumah sakit dapat menghasilkan dampak positif berupa produk pelayanan kesehatan yang baik terhadap pasien dan memberikan keuntungan retribusi bagi pemerintah dan lembaga pelayanan itu sendiri, rumah sakit juga dapat menimbulkan dampak negatif berupa pengaruh buruk kepada manusia, seperti sumber penularan infeksi nosokomial dan menghambat proses penyembuhan serta pemulihan penderita. Infeksi nosokomial dapat disebabkan adanya tingkat papar penderita oleh mikroba yang potensial pathogen yang dimilikinya maupun mikroba pathogen yang berasal dari penderita lain di rumah rumah sakit (Indan Entjang, 2005, h: 56)

Infeksi nosokomial melalui udara disebabkan oleh adanya aktifitas manusia seperti bersin, batuk, berbicara, dll.Setiap tetesan tersebut dapat berisi ribuan mikroba yang diperkirakan jumlah bakteri dalam satu kali bersin berkisar antara 10.000 sampai 100.000.terdapat dua cara utama penyebaran mikroba yaitu dengan kontak (baik langusng maupun tidak langsung), dan penyebaran melalui udara. Keberadaan kuman udara dipengaruhi oleh suhu, kelembaban, pencahyaan, pelaksanaan desinfeksi, luas lubang ventilasi dan kepadatan hunian (Michael J. Pelczar dan Novi Supriyatti).

Kualitas udara yang buruk akan membawa dampak negatif terhadap pekerja/karyawan berupa keluhan gangguan kesehatan. Dampak pencemaran udara dalam ruangan menurut (corie I.P.,J. Mukono, dan Sudarmaji, 2005, h.162) tubuh terutama pada daerah tubuh organ sebagai berikut : Iritasi selaput lendir (Iritasi mata, mata pedih, mata merah, mata berair). Iritasi hidung (bersin, gatal).Iritasitenggorokan (sakit menelan, gatal, batuk kering).Gangguan neurotoksik (sakit kepala, lemah/capai, muah tersinggung, sulit berkonsentrasi).Gangguan paru dan pernafasan (batuk, nafas berbunyi/mengi, sesak nafas, rasa berat di dada).Gangguan kulit (kulit kering, kulit gatal).Gangguan saluran cerna (diare/mencret).Lainlain (gangguan perilaku, gangguan saluran kencing, sulit belajar).

Tujuan penelitian ini adalah Untuk mengetahui perbedaan jumlah angka kuman udara di ruang perawatan Kelas 3 di IRNA I RSUD Prof. Dr. Margono Soekarjo Purwokerto.

\section{BAHAN DAN METODE}

Jenis penelitian yang dilakukan yaitu penelitian observasional analitik dengan metode pendekatan cross sectioanal yaitu peneliti terhadap angka kuman udara dan lingkungan fisik, yaitu suhu, kelembaban, pencahayaan, luas lubang ventilasi, lantai, dinding, langit-langit, pintu, jendela, dan kepadatan hunian.

Populasi dalam penelitian ini adalah Ruang Perawatan kelas 3 di IRNA I berjumlah 10 ruang pada bangsal Mawar dan 2 ruang pada bangsal Cendana dan sampel pada penelitian ini Ruang Perawatan kelas 3 di IRNA I berjumlah 5 ruang pada bangsal Mawar dan 2 ruang pada bangsal Cendana.

Uji statistik yang digunakan adalah uji One Sampel Test.

\section{III.HASIL DAN PEMBAHASAN}

Sesuai hasil pengukuran suhu di ruang perawatan kelas 3 di IRNA I diperoleh hasil suhu antara $28^{\circ} \mathrm{C}-$ $30 \quad{ }^{\circ} \mathrm{C}$ dengan rata-rata 29,28 ${ }^{\circ} \mathrm{C}$.Menurut KEPMENKES RI No 1204/MENKES/X/2004 tentang Persyaratan Kesehatan Lingkungan Rumah Sakit diketahui suhu di ruang perawatan distandarkan $22-24{ }^{\circ} \mathrm{C}$, hasil pengukuran di atas, suhu pada ruang perawatan kelas 3 di IRNA I tidak memenuhi standar yang sudah ditentukan.

Hasil pengukuran kelembaban di ruang perawatan kelas 3 di IRNA I diperoleh hasil kelembaban antara $61-68 \%$ dengan rata-rata 64\%.Menurut KEPMENKES RI No. 1204/MENKES/SK/X/2004 tentang Persyaratan Kesehatan Lingkungan Rumah Sakit yang menerangkan kelembaban di ruang perawatan distandarkan $45-60 \%$, hasil pengukuran tersebut, kelembaban pada ruang perawatan kelas 3 di IRNA I tidak memenuhi standar yang ditentukan.

Hasil pengukuran pencahayaan di ruang perawatan kelas 3 di IRNA I diperoleh hasil pencahayaan antara 140 - 252 lux dengan rata-rata 201,42 lux. Menurut KEPMENKES RI No. 1204/MENKES/SK/X/2004 tentang Persyaratan Kesehatan Lingkungan Rumah Sakit yang menerangkan pencahayaan di ruang perawatan distandarkan 100-200 Lux, hasil pengukuran tersebut, pencahayaan di ruang perawatan kelas 3 di IRNA I pada ruang Mawar 9, Mawar 8, dan Mawar 7 tidak memenuhi syarat, sedangkan ruang yang lain sudah memenuhi syarat.

Hasil pengukuran luas ventilasi di ruang perawatan kelas 3 di IRNA I diperoleh hasil luas ventilasi antara 2,60 - 2,97 \% dengan rata-rata 2,86\%.MenurutKEPMENKES RI No. 1204/MENKES/SK/X/2004 tentang Persyaratan Kesehatan Lingkungan Rumah Sakit yang menerangkan luas lubang ventilasi di ruang perawatan distandarkan $15 \%$ dari luas lantai.Dari seluruh ruang perawatan kelas 3 di IRNA I tidak ada yang memenuhi persyaratan.

Hasil pengukuran kepadatan pasien di ruang perawatan kelas 3 di IRNA I diperoleh hasil antara $2,9-10,5 \mathrm{~m}^{2} /$ orang dengan rata-rata $6,08 \mathrm{~m}^{2} /$ orang. Menurut KEPMENKES RI No. 829/MENKES/SK/II/1999 tentang Persyaratan Kesehatan Perumahan yang menerangkan 1 (satu) orang minimal menempati luas rumah $4 \mathrm{~m}^{2}$. 
Pada ruang perawatan Mawar yang terdiri dari kamar 9, kamar 8, kamar 7, dan kamar 3, dengan ruangan yang berukuran $42 \mathrm{~m}^{2}$, masing-masing kamar terdapat 6 tempat tidur, 6 meja, dan 6 kursi. Pada ruang Mawar ini terdapat jendela dan pada masing-masing ruang suadah terdapat fan, jumlah fan pada setiap ruang adalah 1 (satu) buah. Pada bagian dinding dan lantai dalam keadaan kokoh, bersih, dan dicat menggunakan warna terang, lantai sudah menggunakan keramik, tidak licin, dan pertemuan lanatai dengan dinding berbentuk konus ( bukan sudut mati ) sehingga mudah dibersihkan. Kondisi langit-langit sudah bersih, kokoh, tidak rawan kecelakaan, dan bebas dari serangga dan tikus.Pintu dalamkondisi kuat dan baik sehingga masih dapat mencegah masuknya serangga dan tikus.

Pada ruang perawatan Cendana yang terdiri dari kamar 1 dan 2, kamar tersebut berukuran $96 \mathrm{~m}^{2}$, pada kamar Cendana 1 dan 2 terdapat 18 tempat tidur, 18 meja, dan 18 kursi. Pada ruang Cendana ini terdapat jendela dan menggunakan fan, jumlah fan pada kamar Cendana 1 dan 2 berjumlah 2 (dua). Pada bagian dinding dan lantai dalam keadaan kokoh, bersih, dan dicat menggunakan warna terang, lantai sudah menggunakan keramik, tidak licin, dan pertemuan lanatai dengan dinding berbentuk konus ( bukan sudut mati ) sehingga mudah dibersihkan. Kondisi langit-langit sudah bersih, kokoh, tidak rawan kecelakaan, dan bebas dari serangga dan tikus.Pintu dalam kondisi kuat dan baik sehingga masih dapat mencegah masuknya serangga dan tikus.

Pelaksaan desinfeksi pada ruang perawatan kelas 3 di IRNA I tidak rutin dan jarang dilakukan, tergantung dari permintaan ruangan yang ingin di desinfeksi karna melihat ruangan yang selalu terisi oleh pasien, setelah pasien keluar langsung terisi oleh pasien baru, sehingga ruangan jarang sekali dalam keadaan kosong atau tidak ada pasien.Terakhir pelaksanaan desinfeksi pada ruang perawatan kelas III di IRNA I yaitu ruang Cendana 1 tanggal 16 Maret 2015, Cendana 2 tanggal 30 Maret 2015, Mawar 9 tanggal 29 Mei 2015, Mawar 8 tanggal 9 April 2015, Mawar 3 tanggal 2 April 2015, Mawar 7 tanggal 20 Mei 2015, dan Mawar 6 tanggal 23 April 2015. Dari waktu pengambilan sampel kuman udara pada bulan Juni, kamar Cendana memang sudah cukup lama pelaksanaan desinfeksinya, karena kamar Cendana hanya terdapat dua rungan, kapasitas tempat tidur pasien juga cukup banyak, sehingga membutuhkan waktu cukup lama menunggu ruangan kosong untuk dilaksanakan desinfeksi. Ruangan yang lama tidak dilaksanakan desinfeksi akan menimbulkan jumlah angka kuman udara bertambah dan berpotensi terjadinya infeksi nosokomial.

Angka kuman udara di ruang perawatan kelas 3 di IRNA I diperoleh hasil angka kuman udara antara 2.500-85.500 $\mathrm{CFU} / \mathrm{m}^{3}$ dengan rata-rata 31714,2857 $\mathrm{CFU} / \mathrm{m}^{3}$.Menurut KEPMENKES RI No. 1204/MENKES/SK/X/2004 tentang Persyaratan Kesehatan Lingkungan Rumah Sakit yang menerangkan angka kuman di ruang perawatan disyaratkan 200-500 CFU/m³ . Berdasarkan hasil pengukuran tersebut, ruang kelas 3 di IRNA I RSUD Prof. Dr. Margono Soekarjo Purwokerto tidak ada yang memenuhi persyaratan.

Menurut hasil perhitungan menggunakan SPSS versi 17.0 dengan rumus One Sample Test, diketahui rata-rata angka kuman udara di ruang perawatan kelas 3 di IRNA I adalah31714.2857, rata-rata angka kuman di ruangan tersebut tidak memenuhi persyaratan KEPMENKES RI No. 1204/MENKES/SK/X/2004 tentang Persyaratan Kesehatan Lingkungan Rumah Sakit yang menerangkan angka kuman di ruang perawatan distandarkan 200-500 CFU/m $\mathrm{m}^{3}$. Nilai signifikan 0,058 $>\alpha$ berarti Ho di tolak, hal tersebut menunjukan bahwa tidak ada perbedaan yang bermakna antara jumlah angka kuman pada kelas III di IRNA I RSUD Prof. Dr. Margono Soekarjo Purwokerto.

\section{IV.SIMPULAN}

Suhu pada ruang perawatan kelas 3 di IRNA I antara $28^{\circ} \mathrm{C}-30^{\circ} \mathrm{C}$.Suhu ruang perawatan kelas $3 \mathrm{di}$ IRNA I tidak memenuhi syarat yaitu 22-24 ${ }^{\circ}$ C.Kelembaban pada ruang perawatan kelas 3 di IRNA I antara 61\% - 68\%.Kelembaban ruang perawatan kelas 3 di IRNA I tidak memenuhi syarat yaitu 45-60 \%.Pencahayaan pada ruang perawatan kelas 3 di IRNA I antara 140 lux - 252 lux.Pencahayaan ruang perawatan kelas 3 di IRNA I sebagian sudah memenuhi syarat dan sebagian belum yaitu distandarkan 100-200 lux.

Kondisi sanitasi berupa kebersihanlantai, kebersihan dinding, kebersihan langit-langit, pintu dan jendela pada ruang perawatan kelas III di IRNA I termasuk dalam keadaan baik yang sudah memenuhi standar KEPMENKES RI Nomor : 1204/MENKES/SK/X/2004 tentang Persyaratan Kesehatan Lingkungan Rumah Sakit.

Angka kuman udara pada ruang perawatan kelas di IRNA I adalah 2.500 CFU $/ \mathrm{m}^{3}-85.500 \mathrm{CFU} / \mathrm{m}^{3}$. Penelitian angka kuman udara yang telahh dilakukan diperoleh nilai sig $0,058>\alpha$ berarti Ho ditolak, sehingga tidak ada perbedaan yang bermakna antara jumlah angka kuman pada kelas III di IRNA I RSUD Prof. Dr. Margono Soekarjo Purwokerto.

\section{DAFTAR PUSTAKA}

Departemen Kesehatan RI. 2004. Keputusan Menteri Kesehatan Republik Indonesia Nomor 1204/MENKES/SK/X/2004 tentang Persyaratan Kesehatan Lingkungan Rumah Sakit. Jakarta : Departemen Kesehatan RI.

Candra, Diah. M. 2012. Studi Komparasi Jumlah Angka Kuman Udara Ruang Perawatan Kenanga Kelas 2 dan 3 di RSUD Prof. Dr. Margono Soekarjo Purwokerto makalah pada Kuliah Perdana Semester Genap TA. 
2012/2013. Purwokerto : Jurusan Kesehatan Lingkungan Purwokerto.

Entjang I. 2003. Mikrobiologi dan Parasitologi. Bandung : PT. Citra Aditya Bakti.

Mikrobiologi Udara. diakses at http://mikrobiologiudara.blogspot.com/ pada tanggal 2 Januari 2015 pukul 20.15 WIB.

Suripatty, N. 2008. Kajian Kualitas Udara Beberapa Rumah Sakit di Provinsi Maluku. Jurnal : Maluku.

Departemen Kesehatan RI. 2002. Keputusan Menteri Kesehatan Republik Indonesia Nomor 1334/MENKES/X/2002 tentang Standar Operasional Pengambilan dan Pengukuran Sampel Kualitas Udara Ruangan Rumah Sakit. Jakarta : Departemen Kesehatan RI.

Departemen Kesehatan RI. 2009. Undang - undang Republik Indonesia Nomor 44 Tahun 2009 Rumah Sakit.
Cahyono T. 2008. Pedoman Penulisan Proposal Penelitian dan Karya Tulis Ilmiah/ Skripsi Edisi Revisi Ketiga. Purwokerto : Kementerian Kesehatan RI Politeknik Kesehatan Semarang Jurusan Kesehatan Lingkungan Purwokerto.

Pelezar, M.J. dan ECS Chan. 2008. Dasar - dasar Mikrobiologi. Jakarta : Universitas Indonesia

RSUD Prof. Dr. Margono Soekarjo Purwokerto. Profil RSMS. Diakses at http://www.rsmargono.go.id/ pada tanggal 5 Januari 2015 pukul 19.00 WIB.

Suparmin. 2008. Hubungan Kualitas Lingkungan Fisik dengan Angka Kuman Udara Ruang Perawatan di RSUD Prof. Dr. Margono Soekarjo Purwokerto. Makalah pada Kuliah Perdana Semester Genap TA. 2008/2009. Purwokerto : Jurusan Kesehatan Lingkungan Purwokerto.

Waluyo L. 2004. Mikrobiologi Umum. Malang : Universitas Muhammadiyah Malang. 